\title{
Towards the integrated assessment of New Zealand pastoral farm systems
}

\author{
M.B. DODD ${ }^{1}$ and D.R. STEVENS ${ }^{2}$ \\ ${ }^{1}$ AgResearch, Grasslands Research Centre, Private Bag 11008, Palmerston North 4442, New Zealand \\ ${ }^{2}$ AgResearch, Invermay Research Centre, Private Bag 50034, Mosgiel, New Zealand \\ mike.dodd@agresearch.co.nz
}

\begin{abstract}
Land use and management change is a feature of New Zealand farm systems, driven by a range of factors including volatile markets and exchange rates, variable weather and climate patterns, continuous policy evolution and the inherent innovation of New Zealand farmers. Yet the common indicators used to evaluate the impact of change appear to be limited to the link between productivity (of land/labour/capital) and profitability. However, if farm system "owners" seek truly sustainable systems they should consider a wider set of indicators to guide investment. Sustainability is considered in terms of the ability of the pastoral farm system to fulfil its primary purpose in the long-term, i.e. "to derive value from the natural capital of a land and water resource that is sufficient to support the objectives of the resource owner" and fulfil secondary objectives considered important by other stakeholders (e.g., product and environmental quality). The objective of this study was to develop an integrated assessment framework for sustainability indicators that was useful for guiding change decisions at the farm system scale, a key determinant of regional economic, environmental and social outcomes. The approach is based on the fundamental properties of a complex adaptive system: existence, effectiveness, freedom of action, security, adaptability and coexistence, applied to six key system drivers (financial, environmental, social, cultural, technological and regulatory). This framework could support decision-making in terms of the investment of human, natural and financial capital at the farm system scale and contribute to larger scale information imperatives (e.g., value chains, catchments).
\end{abstract}

Keywords: integrated assessment, pastoral farm systems, sustainability, systems properties

\section{Introduction}

Land use and management change is a feature of New Zealand pastoral farm systems (Macleod \& Moller 2006), driven by a range of factors operating at various scales, including volatile markets and exchange rates, variable weather and climate patterns and continuous policy evolution. Figure 1 categorises these drivers with some examples at global, domestic, regional and local scales. In this context, questions

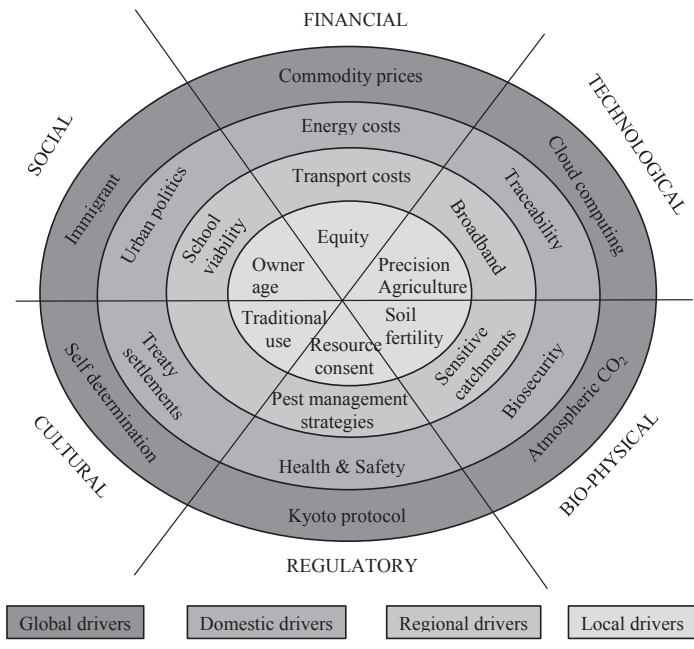

Figure 1 Examples of multiple drivers of change, at scales from global to local, impacting on New Zealand pastoral farm systems.

around the sustainability of pastoral farm systems constantly emerge, fuelled by observations of sectoral trends such as the loss of elite pastoral land to urban sprawl (Rutledge et al. 2010), declining soil quality (MfE 2015), increasing regulatory compliance costs (Journeaux 2015) and growing debt (MPI 2012). Faced with such pressures a farm system must behave as a complex adaptive system, that is, an entity that uses strategies to achieve outcomes in interaction with other systems, and which evolves in response to the results of those interactions (Axelrod \& Cohen 1999).

In response to these challenges, the inherent innovation capacity of New Zealand farmers (Thorrold 2010) has resulted in high levels of land use and management change, including such features as the expansion of irrigation, use of a wide variety of supplementary feeds beyond "home-grown" pasture, shifts in animal enterprises, small-scale forestry, sheep reproductive efficiency gains and pasture renewal. All of these changes involve an investment by the owner of financial and human capital (i.e., time and acquired knowledge). Yet the common indicators used to evaluate the impact of change appear to be limited to the link between operational profit and the productivity of capital (land/labour/equity), set against the costs 
associated with transformation of the farm system, in the context of an investment analysis (Kerr et al. 2007). However, Frame \& O'Connor (2011) describe a threshold beyond which the quality and relevance of monetary valuations diminishes with increasing system complexity and diversity of values. If the aim of the owner is to develop sustainable farm systems within the system of drivers indicated in Figure 1, they will need to consider a wider set of indicators to guide investment. This is because governance must consider the increasing degree to which farm systems are both influenced by, and themselves influence, other systems with their own governance structures. Examples of the direct influence of farm systems on other systems include impacts on aquatic environments and rural communities; examples of the direct influence of other systems on farm systems include the impacts of climate change and urban expansion. This means that in future investment decisions it will become more common to consider the interests of a wider set of stakeholders, who themselves account for a wider range of sustainability outcomes from farm systems (Dodd et al. 2008).

The objective of this study was to develop an integrated assessment (IA) framework that included relevant sustainability indicators useful for guiding change decisions at the farm system scale. Decision-making at this scale has profound effects on regional landscapes, economies and communities, but the tools available are limited and key indicators are often developed and imposed by technocrats and policymakers, leading to limited relevance for practitioners (Reed et al. 2008). The purposes of IA can be varied, including:

1. Analytical, for identifying issues or problems not immediately apparent;

2. Educational, for building systems understanding;

3. Aspirational, for monitoring the progress of a particular system over time relative to a set of goals or benchmarks;

4. Commercial, the comparison of different systems for point-of-difference marketing;

5. Operational, for supporting investment/disinvestment decision-making.

These purposes can be expected to influence the type of tools developed to meet the needs of the assessment. A focus on monitoring progress towards stated goals might be narrowly restricted to a few key performance indicators relevant to those goals (e.g., equity). A focus on point-of-difference marketing might require information on a currently high profile indicator (e.g., food miles). Support for investment decisions may require modelling to account for uncertainty. It is this last operational purpose that the present analysis is aimed at.

\section{Existing agricultural system indicator frameworks} In the decades following the "Brundtland Report" (WCED 1987) that brought the concept of sustainable development to the forefront of policy and research globally, countless sustainable development indicator (SDI) frameworks have been developed that largely focus on the purpose of guiding systems at various scales toward progress across multiple goals (e.g., UN, OECD \& EU frameworks, see Geniaux et al. 2005) . In New Zealand, the "Sustainability Dashboard" has recently been developed as a tool for enterprises in the primary sector to assess their current sustainability performance (Hunt et al. 2014). This tool is well aligned with international frameworks and has a strong focus on governance that many indicator frameworks lack, as they are often focussed on the three original UN sustainable development pillars of economy, environment and society. Version 1 includes a comprehensive 109 individual indicators that contribute to 54 objectives and 19 outcomes within four pillars: Good governance, Economic resilience, Agrienvironmental integrity and Social well-being.

Two other New Zealand efforts in IA are worth noting. The Whatawhata Integrated Catchment Management project elicited a set of goals and indicators from multiple decision-maker representatives. These were used for assessing the current status of a small catchment farm and its progress towards "a well-managed rural hill country catchment" following land use and management changes (Dodd et al. 2008). The framework is idiosyncratic in the sense that it was focused on hill country and developed by a specific group without external validation, but it has the advantage of being decision-maker centric (rather than being theoretically derived) and thus likely to have higher engagement potential. Their six high level goals included a) business viability; b) ecosystem health; c) active partnerships; d) demonstrable environmental performance; e) adequate rural infrastructure; f) protected landscape values. The Ballance Farm Environment Awards uses a form of indicator framework for the purpose of monitoring progress toward environmental performance in the sector. A judging handbook and reference checklist is used by a panel of selected experts to gather information on farmer entrants across four broad areas: a) sustainable profitability, b) environmental awareness, c) good business practise and d) social and community responsibility, to answer the question "Can what is being done now, still be working successfully in 100 years?" This approach emphasises the utility of multiple brains in drawing conclusions about the relative sustainability of a given system.

Van Cauwenbergh et al. (2007) contrast such "content-based" approaches with "system-based" approaches, in which indicators are based on 
fundamental system properties (Geniaux et al. 2005). A number of such attempts to connect indicators to system properties in an agricultural context exist, including the Agro-Ecosystem Analysis (AEA, Conway 1994), the Framework for Evaluating Sustainable Land Management (FESLM, Smyth \& Dumanski 1993) and the Framework for Assessing Natural Resource Management Systems (MESMIS, Lopez-Ridaura et al. 2002). These IA frameworks are structured on the basis of concepts such as productivity, stability, resilience, adaptability, equity and security.

Bossel (2000, 2001) provides a summary of fundamental system properties for any complex adaptive system, referred to as system orientors. The properties are considered non-substitutable, in that excess capacity in one cannot cover a deficiency in another:
1. Existence, the system must be compatible with its normal environment in that the necessary inputs are available (e.g., information, energy, nutrients);

2. Efficacy, the system must be able to secure scarce resources and fulfil its purpose (e.g., produce meat, make a profit);

3. Freedom of action, the system must be able to function in an environment containing a variety of influences (e.g., topography, regulations);

4. Security, the system must be able to function under environmental variability (e.g., fluctuations in climate or input prices);

5. Adaptability, the system must be able to re-organise to operate when the environment changes permanently (e.g., a new regulation, loss of market);

6. Co-existence, the system must be able to modify

Table 1 A proposed framework of questions and potentially quantifiable indicators (italics) or tools (bold) that would provide a broader integrated assessment of the comparative sustainability of a pastoral farm system. Social and cultural drivers are combined in a column, as are Environmental and Technological drivers.

\begin{tabular}{|c|c|c|c|c|c|}
\hline Drivers & $\begin{array}{l}\text { Systems } \\
\text { Properties }\end{array}$ & Financial & Social/cultural & $\begin{array}{l}\text { Environmental/ } \\
\text { Technological }\end{array}$ & Regulatory \\
\hline Existence & $\begin{array}{l}\text { (compatible with } \\
\text { normal } \\
\text { environment) }\end{array}$ & $\begin{array}{l}\text { Are the input and } \\
\text { capital costs be } \\
\text { serviceable? } \\
\text { Forecast budget }\end{array}$ & $\begin{array}{l}\text { Does the system } \\
\text { have access } \\
\text { to adequate } \\
\text { governance and } \\
\text { labour? } \\
\text { Personnel units }\end{array}$ & $\begin{array}{l}\text { Are the required } \\
\text { bio-physical inputs } \\
\text { available? } \\
\text { Soil fertility, fuel, } \\
\text { animal feed }\end{array}$ & $\begin{array}{l}\text { Does the system have } \\
\text { a legal mandate? }\end{array}$ \\
\hline Effectiveness & $\begin{array}{l}\text { (efficient in } \\
\text { resource use) }\end{array}$ & $\begin{array}{l}\text { Does the system } \\
\text { add value? } \\
\text { Surplus, IRR } \\
\text { Investment } \\
\text { analysis }\end{array}$ & $\begin{array}{l}\text { Does the system } \\
\text { support owner } \\
\text { goals? } \\
\text { Contentment, } \\
\text { Recreation time }\end{array}$ & $\begin{array}{l}\text { Can the system } \\
\text { produce adequate } \\
\text { outputs? } \\
\text { Animal production } \\
\text { Farm system } \\
\text { model }\end{array}$ & $\begin{array}{l}\text { Does the system } \\
\text { meet relevant quotas? } \\
\text { Supply contracts }\end{array}$ \\
\hline Freedom of action & $\begin{array}{l}\text { (responsive to } \\
\text { environmental } \\
\text { variety) }\end{array}$ & $\begin{array}{l}\text { Does the system } \\
\text { have flexible cash- } \\
\text { flow arrangements? } \\
\text { Overdraft limit }\end{array}$ & $\begin{array}{l}\text { Does the system } \\
\text { enable greater } \\
\text { wisdom? } \\
\text { Education, } \\
\text { knowledge }\end{array}$ & $\begin{array}{l}\text { Can the system } \\
\text { minimise losses? } \\
\text { Nutrient surplus } \\
\text { Nutrient budget }\end{array}$ & $\begin{array}{l}\text { Is the system policy } \\
\text { compliant? } \\
\text { Resource consent, } \\
\text { H\&S, Animal welfare }\end{array}$ \\
\hline Security & $\begin{array}{l}\text { (responsive to } \\
\text { environmental } \\
\text { variability) }\end{array}$ & $\begin{array}{l}\text { Can the system } \\
\text { cope with changes } \\
\text { in input/output } \\
\text { prices? } \\
\text { Sensitivity } \\
\text { analysis }\end{array}$ & $\begin{array}{l}\text { Does the system } \\
\text { require additional } \\
\text { training and } \\
\text { learning? } \\
\text { Training time }\end{array}$ & $\begin{array}{l}\text { Can the system } \\
\text { cope with pest and } \\
\text { disease incursions? } \\
\text { Animal health plan }\end{array}$ & $\begin{array}{l}\text { Does the system } \\
\text { comply within all } \\
\text { relevant jurisdictions? }\end{array}$ \\
\hline Co-existence & $\begin{array}{l}\text { (compatible with } \\
\text { interacting systems) }\end{array}$ & $\begin{array}{l}\text { Does the system } \\
\text { have good } \\
\text { standing? } \\
\text { Credit rating }\end{array}$ & $\begin{array}{l}\text { How will community } \\
\text { relations be affected } \\
\text { by the system? } \\
\text { Social networks }\end{array}$ & $\begin{array}{l}\text { Are there cross- } \\
\text { contamination } \\
\text { issues with external } \\
\text { systems? } \\
\text { Sediment losses }\end{array}$ & $\begin{array}{l}\text { Does the system } \\
\text { meet market } \\
\text { compliance? } \\
\text { QA audit }\end{array}$ \\
\hline
\end{tabular}


its behaviour to account for the interests of other neighbouring systems (e.g., banks, catchments).

While this structure covers the attributes that would need to be considered in any integrated assessment, developing quantitative indicators that are readily recognisable to farmers may be challenging (i.e. indicators in the form of stocks, e.g., soil phosphorus content; flows, e.g., pasture growth; or ratios, e.g., gross margin per stock unit).

\section{A proposed approach}

A proposed integrated assessment framework for a farm system (Table 1) focuses on assessing six fundamental system properties of (Bossel 2000, 2001) across four drivers. In reference to Figure 1, social plus cultural drivers and environmental plus technological drivers are combined into one column each. Each cell in Table 1 considers how the four drivers might impact on those properties and poses an example question as to whether the system of interest is resilient to those drivers. These examples of questions, quantitative indicators and tools are not exclusive or complete, but are offered as a starting set for further discussion and development.

\section{Discussion}

One of the key challenges with existing IA frameworks is the risk of data overload. Many of those that adopt an approach based on UN sustainable development pillars (economic, environmental, social, cultural) include large tables with a dizzying array of indicators that have limited use at the farm system scale. In addition, the data gathering required to support comprehensive reporting at the farm scale is likely to be onerous and the challenge of balancing all these goals could be paralysing to decision-making. Hence, the need for an alternative approach.

For the owner of a complex adaptive system such as a farm system, decision-making is itself a complex process, as shown by the challenges associated with the effective extension and implementation of research (Rhodes et al. 2016). Smeaton \& Dooley (2008) note that financial factors account for $50 \%$ of the influence on decision-making in mixed livestock farms, consistent with the assertion that financial modelling alone becomes less valuable as system complexity and diversity of values increases (Frame \& O'Connor 2011). It is suggested that at a very simple level, three elements contribute to a change decision: 1) dissatisfaction with the current situation; 2) a clear picture of a better future; and 3) a feasible pathway of implementation. In lay language: 1) "What is the real problem?"; 2) "What's in it for me?" and; 3) "Can I see myself doing it?" Another way of interpreting the purpose of a useful integrated assessment framework is that it attempts to address these fundamental questions. The framework in Table 1 can readily address the first issue, and by posing "Will..." questions rather than "Does..." questions can address the second issue. The third issue is addressed by questions relating to capability in the Social/Cultural column.

Hansen (1996) suggests four paradigms for defining agricultural sustainability that will influence an IA framework. Specifically, 1) an ideology or philosophy (e.g., diversity, self-sufficiency; 2) a set of strategies (e.g. biological, organic) whereby indicators may be based on adherence to particular practices; 3 ) the ability to satisfy diverse goals, whereby indicators may be based on multiple quantitative measurements; and 4) the ability to persist, whereby indicators may be based on trends over time. The latter two paradigms are critically relevant to the purpose of supporting decision-making in pastoral systems. While a relevant sustainability framework must be founded on the primary purpose of a system, it must also recognise the importance of a wider stakeholder group in defining purposes at larger scales (e.g., value chains, catchments). A definition of the primary purpose of a pastoral farm system is to "derive value from the natural capital of a land and water resource that is sufficient to support the objectives of the resource owner". Pastoral farming activity represents the first two stages in the primary production value chain: the conversion of soil natural capital to harvestable plant biomass, and the conversion of harvestable plant biomass to saleable animal biomass. The effectiveness of these transformations are critical to the output of the system and appropriately reflected in traditionally used performance indicators (pasture growth and animal production). The value dimension embodied in the purpose statement likewise justifies a traditional focus on profitability and return on capital indicators. Therefore, properties such as existence and effectiveness are critical in this regard, across financial, environmental and social dimensions.

However, with regard to the production of "secondary" outputs (those not critical to the sustainability of the system), so much of the focus of sustainability indicator frameworks appears to be on these secondary outputs, largely because they relate to the sustainability of systems at higher scales (e.g., the catchment, the value chain, financial networks) and thus the needs or perceptions of a wider group of stakeholders at that larger scale. The relevance of these stakeholder needs to the sustainability of the farm system resides in their influence on the ability of the farm system to access inputs, maintain internal processes and market primary outputs, essentially the system's "freedom of action" and "coexistence" (Bossel 2000). For example, secondary outputs of "excessive" nutrients/sediments is translated by catchment-scale stakeholders into a key information input in the form of regulation; or "poor" livestock welfare is translated into a key system output in the form of market access. Such regulation appears 
to occur in three main areas that can all be related to the "safety" of various system components: environmental safety (pollution); human safety (health and food security) and animal safety (welfare).

The framework also accounts for such externalities as the vulnerabilities of input sources and upscale impacts of outputs. In the social/cultural dimension, key drivers of human behaviour are considered, e.g., the desire for work-life balance, increasing wisdom, mana/kudos within the peer group, and provision for the next generation. The adaptability property addresses questions around future-proofing the business. Clearly some areas need deeper consideration of appropriate tools and indicators, as these are currently less widely recognised. The specific indicators to be chosen will be those that adequately represent the key outcomes to be delivered by the system to meet the stated purpose. These can be adapted to suit the situation and be scaled to fit the system boundaries that should be defined beforehand. This framework could thus support decision-making in terms of the investment of human, natural and financial capital at the farm system scale and contribute to larger scale information imperatives (e.g., value chains, catchments).

\section{ACKNOWLEDGEMENTS}

This work was financially supported by an AgResearch Core Funding project "Future Farm Systems". Thanks to the project team (Robyn Dynes, Warren King, Stewart Ledgard, Cecile deKlein, Alec Mackay, Oscar Montes de Oca Munguia and David Scobie) for stimulating discussion and to James Turner for feedback on an earlier version.

\section{REFERENCES}

Axelrod, R.; Cohen, M.D. 1999. Harnessing Complexity: Organizational Implications of a Scientific Frontier. The Free Press, New York.

Bosse1, H. 2000. Policy assessment and simulation of actor orientation for sustainable development. Ecological economics 34: 337-355.

Bossel, H. 2001. Assessing viability and sustainability: a systems-based approach for deriving comprehensive indicator sets. Conservation Ecology 5: 12 [online] URL: http://www.consecol.org/vol5/iss2/art12/ accessed 23/5/2016

Conway, G.R. 1994. Sustainability in agricultural development: Trade-offs with productivity, stability and equity. Journal of Farming Systems Research and Extension 4:1-4.

Dodd, M.B.; Wedderburn, M.E.; Parminter, T.G.; Thorrold, B.S.; Quinn, J.M. 2008c. Transformation toward agricultural sustainability in New Zealand hill country pastoral landscapes. Agricultural Systems 98: 95-107.
Frame, B.; O’Connor, M. 2011. Integrating valuation and deliberation: the purposes of sustainability assessment. Environmental Science and Policy 14: 1-10.

Geniaux, G.; Bellon, S.; Deverre, C.; Powell, B. 2005. Sustainable development indicator frameworks and initiatives. SEAMLESS integrated project PD 2.2.1, E.U. $6^{\text {th }}$ Framework Programme. http://www. seamless-if.org

Hansen, J.W. 1996. Is agricultural sustainability a useful concept? Agricultural Systems 50: 117-143.

Hunt, L.; Macleod, C.; Moller, H.; Reid, J.; Rosin, C. 2014. Framework and indicators for 'The NewZealand Sustainability Dashboard': reflecting New Zealand's economic, social, environmental and management values. The NZ Sustainability Dashboard report 13/09. ARGOS. http://www.nzdashboard.org.nz/ uploads/2/3/7/3/23730248/13_09_v1_framework and_kpis_synthesis_report.pdf

Journeaux, P. 2015. Dairying - the cost of production. Journal of Primary Industry Management 19: 8-10.

Kerr, S.; Hendy, J.; Lock. K.; Liang Y. 2007. Estimating the drivers of regional rural land use change in New Zealand. Proceedings of the New Zealand Association of Economists Conference, Christchurch. https:// editorialexpress.com/cgi-bin/conference/download. cgi?db name $=$ NZAE2007\&paper id $=62$

Lopez-Ridaura, S.; Masera, O.; Astier, M. 2002. Evaluating the sustainability of complex socioenvironmental system, the MESMIS framework. Ecological Indicators 2: 135-148.

Macleod, C.J.; Moller, H. 2006. Intensification and diversification of New Zealand agriculture since 1960: An evaluation of current indicators of land use change. Agriculture, Ecosystems and Environment 115: 201-218.

MfE 2015. Environment Aotearoa 2015. Ministry for the Environment, Wellington. $131 \mathrm{pp}$.

MPI 2012. Pastoral input trends in New Zealand: A snapshot. Ministry for Primary Industries, Wellington. 34 pp.

Reed, M.S.; Dougill, A.J.; Baker, T.R. 2008. Participatory indicator development: What can ecologists and local communities learn from each other? Ecological Applications 18: 1253-1269.

Rhodes, A.P.; Casey, M.J.; Payne, T.; Brown, M. 2016. Over the fence: understanding what people do and how they might change. Hill Country Symposium: Grassland Research and Practise Series No. 16: 3945.

Rutledge, D.T.; Price, R.; Ross, C.; Hewitt, A.; Webb, T.; Briggs, C. 2010. Thought for food: impacts of urbanisation trends on soil resource availability in New Zealand. Proceedings of the New Zealand Grassland Association 72: 241-246. 
Smeaton, D.C.; Dooley, A.E. 2008. Adoption of new technologies or management systems on sheep and beef farms. Proceedings of the New Zealand Grassland Association 68: 229-235.

Smyth, A.J.; Dumanski, J. 1993. FESLM. An international framework for evaluating sustainable land management. World Soil Resources Report No. 73. Food and Agriculture Organisation of the United Nations.

Thorrold, B.S. 2010. The future landscape of New Zealand agriculture. Proceedings of the New Zealand Grassland Association 72: 63-66.
Van Cauwenbergh, N.; Biala, K.; Bielders, C.; Brouckaert, V.; Franchois, L.; Garcia Cidad, V.; Hermy, M.; Mathijs, E.; Muys, B.; Reijnders, J.; Sauvenier, X.; Valckx, J.; Vanclooster, M.; Van der Veken, B.; Wauters, E.; Peeters, A. 2007. SAFE-A hierarchical framework for assessing the sustainability of agricultural systems. Agriculture, Ecosystems \& Environment 120: 229-242.

WCED 1987. Our common future. World Commission on Environment and Development. Oxford University Press, Oxford. 400 pp. 